\title{
DETERMINING FOOD SECURITY INDICATORS AT HOUSEHOLD LEVEL IN DROUGHT PRONE AREAS OF THE AMHARA REGION OF ETHIOPIA: THE CASE OF LAY GAINT DISTRICT \\ AREGA BAZEZEW \\ http://dx.doi.org/10.4314/ejesm.v5i4.11
}

Received 23rd July 2012; accepted 21st August 2012

\begin{abstract}
An area exposed to drought and food insecurity and where many people are suffering to get the minimum daily consumption, identifying the population sub-groups or households frequently affected by chronic and/or transitory food security have paramount importance for policy trust. The general objective of the study was to identify food secure and insecure households and map the food insecure agro-ecological zones using indicators in drought prone areas of the Amhara region by using Lay Gaint district as a case study site. Questionnaire survey, in-depth interview and focus group discussions were the major data collection techniques and both quantitative and qualitative methods of analysis were employed. The major variables used for the study includes income, expenditure, dietary diversity, coping strategy and dietary energy. The results of the study showed that sampled households in the study area were prone to food insecurity. The per capita kcal result confirms that around $80 \%$ of the sampled households were food insecure. HDDS showed that sample households were severely constrained in dietary diversity and were highly dependent on only two food groups (cereals and pulses). The results of kcal intake, DDS and food gap analysis showed that Woina-Dega and Kolla agro-ecological zones were the most food insecure zones in the study district. The result evidenced that food availability is a serious problem in the study area that needs enhancing crop production through the application of agricultural inputs. Moreover non-farm activities that supplement the agricultural income have to be given top priority to minimize severe cash constraints of the study households.
\end{abstract}

Keywords: Income, expenditure, dietary diversity, coping strategy, dietary energy, Ethiopia

\section{Introduction}

An area where the majority of the population is exposed to vulnerability to food insecurity as a result of natural and human induced shocks, identifying the most vulnerable groups of people and regions have paramount importance for policy trust. In identifying the food insecure and vulnerable households, major indicator variables could be taken as the starting point for the analysis of food security. This is due to the fact that food security indicators can identify the food secure and insecure households and try to predict how the different segments of the population will be affected by unexpected shocks (Qurish, 2007). Thus, through measurement one can identify regions, sub-groups and households prone to vulnerability to food insecurity.

Debebe (1995) stressed that identifying food security indicators are a difficult tasks as

Department of Geography and Environmental Studies

Bahir Dar University, Ethiopia

aregaberlie@gmail.com there are no universally established measures of food security. This is because food insecurity and hunger which are affected by multiple factors cannot be captured by any single indicator (Bickel et al., 2000). Thus, the search for reliable and valid indicators of food security will remain a major challenge as a result of the multidimensional nature of food security. This might be the reason that Hoddinott (1999) had suggested roughly 450 food security indicators and Frankberger (1992) had listed 25 indicators of food security. Maxwell (2008) suggested that where ever possible, the use of more than one food security indicator is advisable because one indicator could not wholly explain the food security status of the households. For example, households' calorie intake might be greater than 2100, but the availability of food could be from cereals and/or proteins only. In that sense, dietary diversity is considered to be a 
good measure of dietary quality. To this end, the study had selected four major food insecurity indicators such as income and expenditure gap analysis, dietary diversity, coping strategy index and dietary energy supply. Therefore, it was hypothesized that consuming fewer food groups have positive and significant relations to household food insecurity. It was believed that demographic and socio-economic factors have significant relations to household food dietary energy intake.

\section{Methodology}

\section{Description of the Study area}

The study was carried out in Lay Gaint district in the Amhara National Regional State of Ethiopia (Figure 1). The district covers a total area of $1320.3 \mathrm{~km}^{2}$ and it is one of the densely populated woredas in the Region with a population density of 185 persons per $\mathrm{km}^{2}$ (CSA, 2010). The topography is rugged with elevations varying between $1200 \mathrm{~m}$ to above $4000 \mathrm{~m}$ asl. The area receives annual rainfall of $898.3 \mathrm{~mm}$. The mean temperature ranges from $4^{0} \mathrm{C}$ (on the top of Guna mountain) to $28^{\circ} \mathrm{C}$ (at the bottom of the Tekeze river valley). Based on the traditional agroecological classification, three temperature zones are found in the area: Dega (cool) Woina-Dega (temperate) and Kolla (hot tropical). Small scale mixed agriculture is the dominant source of livelihoods to the local people. Barley, wheat, teff and potatoes are the principal crops, and from the livestock cattle, sheep, and goats are the dominant ones.

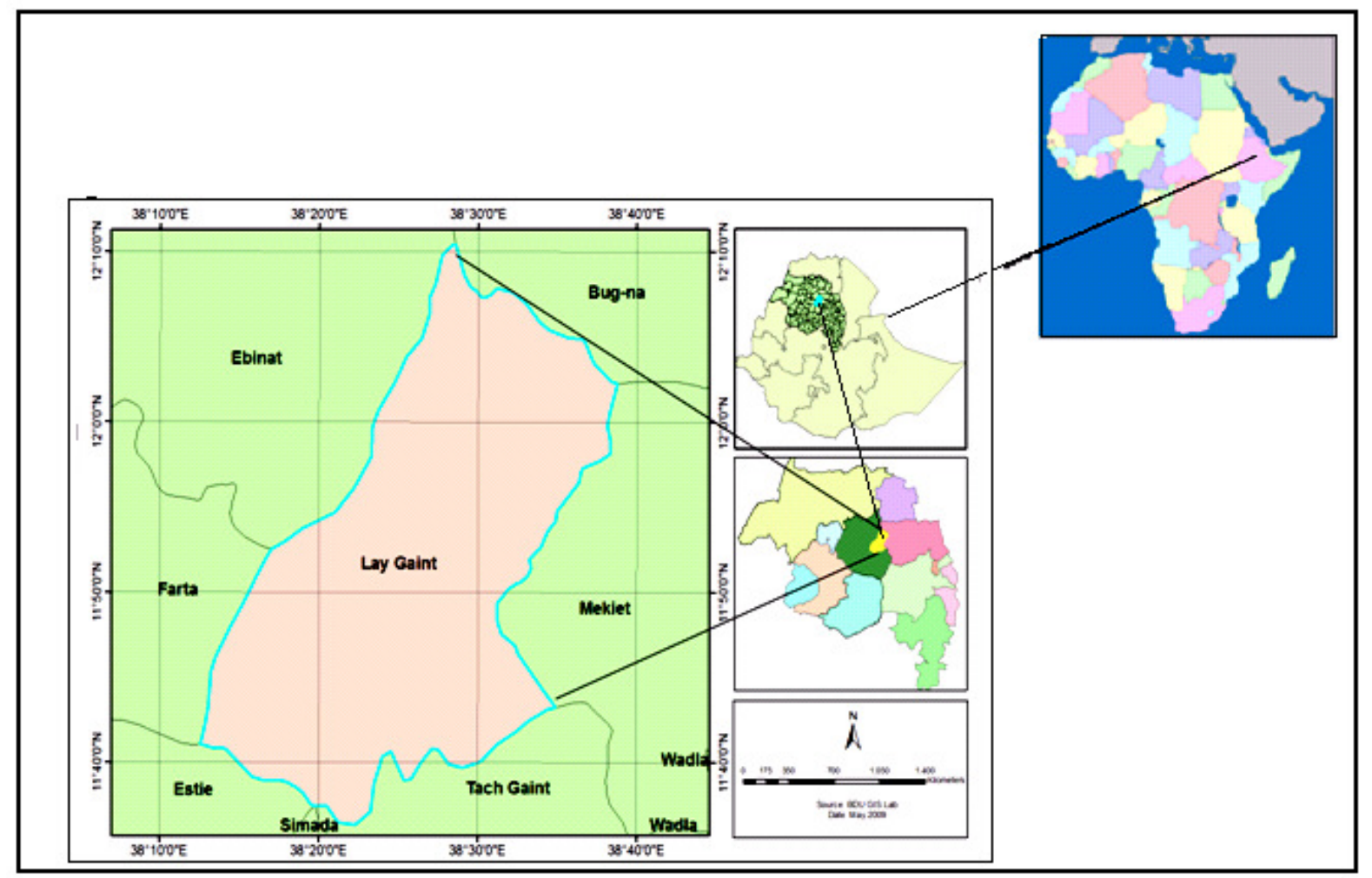

Figure 1 The relative location of Lay Gaint district, Ethiopia

\section{Data collection and analysis}

The study employed purposive, cluster and random sampling methods to select specific sampling sites. Selection of the study district was purposive based on the researcher's prior knowledge of the area. The specific rural kebele administrations (RKAs) the lowest tiers in the administrative structure of the country - were selected in a cluster sampling approach. All the RKAs in the 
district were first clustered into the three major traditional agro-ecological zones (Dega, Woina-Dega and Kolla) and then three RKAs were selected one each from the three zones in a random sampling procedure. The assumption was in similar agro-ecological zones the households share similar opportunity to secure their livelihoods. Households in each RKA were further grouped into wealth categories based on information obtained from focus group discussions, key informants and secondary sources as shown in Table 1. It was assumed that the same shock has different impact on households in different wealth categories. Finally, a total of 201 households were sampled for the questionnaire survey from the three RKAs using proportional stratified random sampling technique based on the sampling frames obtained from the RKA offices. For the qualitative part, a total of six key informant interviews and three focus group discussions (FGDs) were selected in each of the three RKAs. The fieldwork was carried out between March and April 2011.

The survey questionnaire covered issues such as household's source of cash and expenditure, dietary energy and diversity and coping strategy. In-depth interview and focused group discussions were held with the subjects such as future food security status of households and perceptions about rainfall variability and crop production scenarios. The data generated by the structured questionnaire were entered into the statistical package, SPSS (Statistical Package for Social Scientists), and were analyzed using descriptive statistics such as frequencies, tables and percentages. The Qualitative information collected in the field were documented and analyzed textually to substantiate the statistical results from the structured questionnaire.

Table 1 Criteria used for wealth-based categorization of households in the study area

\begin{tabular}{|c|c|c|c|}
\hline Criteria & Better-off & Middle & Poor \\
\hline Family size & $6-12$ & $6-8$ & $4-7$ \\
\hline $\begin{array}{l}\text { Landholding } \\
\text { (ha) }\end{array}$ & $1.75-3.00$ & $1.00-1.75$ & $0-1.00$ \\
\hline $\begin{array}{l}\text { Total annual } \\
\text { income (Birr) }\end{array}$ & 4000 and above & $2600-4000$ & $1100-2600$ \\
\hline Shoats owned & $20-25$ & $10-20$ & $2-7$ \\
\hline Cattle owned & 4 and above & $2-4$ & $0-1$ \\
\hline Oxen owned & 2 and above & $1-2$ & $0-1$ \\
\hline $\begin{array}{l}\text { Other assets } \\
\text { owned }\end{array}$ & $\begin{array}{l}\text { Considerable number of } \\
\text { eucalyptus trees, engaging } \\
\text { in petty trading, own tin } \\
\text { roofed house. }\end{array}$ & $\begin{array}{l}\text { Good quality of grass } \\
\text { thatched and tin roof } \\
\text { houses, } \\
\text { eucalyptus trees }\end{array}$ & $\begin{array}{l}\text { Poor quality of grass } \\
\text { thatched roof and no } \\
\text { significant perennial } \\
\text { trees or assets }\end{array}$ \\
\hline $\begin{array}{l}\text { Food security } \\
\text { status }\end{array}$ & $\begin{array}{l}\begin{array}{l}\text { Consume from } \\
\text { produce }\end{array} \text { throughout the } \\
\text { year. }\end{array}$ & $\begin{array}{l}\text { Consume from own } \\
\text { produce from } 6 \text { to } 8 \\
\text { months }\end{array}$ & $\begin{array}{l}\text { Consume from own } \\
\text { produce not more than } 3 \\
\text { months. }\end{array}$ \\
\hline $\begin{array}{l}\text { Livelihood } \\
\text { activities }\end{array}$ & $\begin{array}{l}\text { Farming, petty trade, lend } \\
\text { money, sell livestock and } \\
\text { crop }\end{array}$ & $\begin{array}{l}\text { Farming and some } \\
\text { form of trade, can } \\
\text { work in safety nets if } \\
\text { necessary }\end{array}$ & $\begin{array}{l}\text { Selling fire wood and } \\
\text { charcoal, daily laborer, } \\
\text { participating in safety } \\
\text { nets }\end{array}$ \\
\hline $\begin{array}{l}\text { Household } \\
\text { head }\end{array}$ & Male headed & $\begin{array}{l}\text { Dominantly } \\
\text { headed }\end{array}$ & Male/female headed \\
\hline
\end{tabular}

Source: Modified from Ellis and Bahiigwa (2003); Ellis and Tassew (2005) 


\section{Measurement of Variables}

Taking into consideration the Hondiott (1999) and Maxwell (2008) coping strategy index and researchers pervious knowledge, all the strategies were weighted against their frequency and severity of occurrences. Accordingly, reducing the quantity of meals, consume less preferred food, migrate to search of job were weighted 1 . Reduce the number of meals, consume seed reserve, harvesting immature food and sale of livestock were weighted 2 and skip food throughout the day, eating wild/famine foods, selling land/house were weighted to 3. Likewise, often, from time to time, rarely and never were counted as 4, 3, 2 and 1, respectively. For the calculation of household dietary diversity, the study had employed Kassie et al. (2008) method of food groupings. The data on household dietary diversity was collected as 1 if they consumed any one of the food groups 0 otherwise.

In the calculation of kcal intake, the amounts of calorie available to a household were determined through an equation which was a modified version of regional food balance model (Mesay, 2009; Eshetu, 2000). The model was constructed as: HHFA = $\mathrm{Y}+\mathrm{FP}+\mathrm{FA}+\mathrm{R} / \mathrm{G}-\mathrm{S}-\mathrm{SR}-\mathrm{PHL}$. Where HHFA = household food availability; $\mathrm{Y}=$ own production; $\mathrm{FP}=$ food purchased; $\mathrm{FA}=$ food aid; R/G = remittance/gift; $\mathrm{S}=$ amount of grain sold; $\mathrm{SR}=$ seed reserves $(5 \%) ; \mathrm{PHL}=$ post harvest loss (10\%). For the study, 2100 kcal per adult equivalent per day was used to identify food insecure households because it is a universal cut-off point (Bogale and Shimelis, 2009).

Linear regression model was selected to identify the determinant variables that influence the per capita kilocalorie consumption at household level. Linear regression model was selected because the dependent variable (per capita kilocalorie intake) was a continuous variable.
The independent variables that explain the per capita dietary energy supply were grouped into natural and socio-economic factors. The socio-economic factors that determine household per capita dietary energy supply include non-farm activities, total production of the household, total livestock and number of oxen owned, total expenditure and income, farm size and number of plots while, the location of geographical places was considered the natural factor.

\section{Results and Discussion \\ Sources of Income and Expenditure}

With the intention to see the cash flow deficit at household level, sources of income and expenditure of the sample households are discussed. In relation to this, Bezabih (1999) suggested that the extent to which farm households are food secure or not can only be assessed if all sources of income and expenditure are discussed and gaps are identified.

\section{Sources of income of the sample households}

Households typically gain access to cash from their own production or through food inflows such as safety nets, food aid and remittances. The sources of income the households surveyed during 2010/2011 crop year were grouped into non-farm and off-farm, agricultural products, food-for-work, gift and remittances (Table 2). The sources of income of the sampled households in the Dega zone were 8 times greater than the Woina-Dega zone. Among the three agro-ecological zones, the Woina-Dega zone was extremely poor in sources of income (birr 302.9 per capita), while the Dega agro-ecological zone was relatively better with a total per capita income of birr 1172.8 per year. The mean income of the sample households in both agro-ecological zones was birr 663.3. Among the sources of income, agricultural products account for $50 \%$ and income from non-farm and off-farm activities constituted only $23.3 \%$ of the total. 
Table 2 Sources of income of the sampled households by agro-ecological zone (in birr)

\begin{tabular}{|l|l|l|l|l|l|}
\hline Sources of income & Dega & $\begin{array}{l}\text { Woina- } \\
\text { Dega }\end{array}$ & Kolla & $\begin{array}{l}\text { Total } \\
\text { income }\end{array}$ & $\begin{array}{l}\text { \% share of the } \\
\text { total income }\end{array}$ \\
\hline Sale of agricultural products & 253,700 & 49,038 & 42,871 & 345,606 & 49.53 \\
\hline $\begin{array}{l}\text { Off-farm and nonfarm } \\
\text { income }\end{array}$ & 111,712 & 11,380 & 39,532 & 162,624 & 23.31 \\
\hline Credit & 34,000 & 18,300 & 30,480 & 82,780 & 11.86 \\
\hline FFW & 29,200 & 19,630 & 15,500 & 64,330 & 9.22 \\
\hline Gift/remittances & 38,155 & 1603 & 2700 & 42,458 & 6.08 \\
\hline Total & 466,767 & 99,948 & 131083 & 697,798 & 100 \\
\hline Per capita income & 1172.8 & 302.9. & 404.6 & 663.31 & \\
\hline
\end{tabular}

As shown in Table 3, the mean income obtained by the comparatively better-off sample households was more than three times of the poor households. Important sources of income for the poor households were agriculture, credit and food-for-work. This is due to the fact that the poor were deprived from the necessary assets to have cash, and hence credit availability and food-for-work could mitigate their cash constraints. On the other hand, the relatively better-off farmers secured their incomes from grain milling and sails from fruits, livestock and grains.

Table 3 Sources of income by wealth categories in 2010/2011 crop year (birr)

\begin{tabular}{|l|l|l|l|l|l|}
\hline Sources of income & Better & Middle & Poor & Total income & $\begin{array}{l}\text { \% share } \\
\text { of total }\end{array}$ \\
\hline Sale of agricultural products & 183,331 & 92,856 & 69,419 & 345,606 & 49.5 \\
\hline Off-farm and nonfarm income & 81,780 & 54,665 & 26,179 & 162,624 & 23.3 \\
\hline Credit & 7000 & 19,040 & 56,740 & 82,780 & 11.9 \\
\hline FFW & 0.0 & 9,085 & 55,245 & 64,330 & 9.22 \\
\hline Gift/remittances & 23,000 & 5,625 & 13,833 & 42,458 & 6.1 \\
\hline Total & 295,111 & 181,271 & 221,416 & 697,798 & 100 \\
\hline Per capita income & 1603.9 & 525.4 & 423.4 & 663.31 & \\
\hline
\end{tabular}

\section{Pattern of Expenditure of the Sampled Households}

So far discussions were made on sources of income to understand how households' access to the different sources of cash, but this cannot be completed without considering households pattern of expenditure on food and non-food items. The major sources of expenditure in the study area are presented in Table 4. The result showed that Dega zone recorded relatively the highest per capita expenditure of birr 985.5 and the average total expenditure per capita per year for all agroecological zones was birr 637. MoFED (2002) report as cited in Samuel (2004) showed that birr 1022.9 per capita expenditure could be taken as the poverty line. Taking this into account, there was a deficit of birr 385.5 for the sampled households in the study area. Table 4 showed that $52 \%$ of the total expenditure spent on food and food related expenses adversely affecting the saving capacity of the households to improve their livelihoods. In relation to this, Alwang et al. (2001) reported that high proportion of total household budget devoted to food is a sign of poverty. In the study area, about $70 \%$ of the total expenditure was devoted to purchase food and payment of obligations. 
Table 4 Sources of expenditure by agro-ecological zone in 2010/2011 crop year (birr)

\begin{tabular}{|l|l|l|l|l|c|}
\hline Expenditure & Dega & Woina-Dega & Kolla & $\begin{array}{l}\text { Total } \\
\text { expenditure }\end{array}$ & $\begin{array}{l}\% \text { from the } \\
\text { total }\end{array}$ \\
\hline Religious festivities & 29,760 & 5,890 & 8,935 & 44,585 & 6.7 \\
\hline Purchase basic food items & 184,569 & 102,974 & 59,628 & 34,7171 & 52.0 \\
\hline $\begin{array}{l}\text { School fee, paying tax and } \\
\text { credit }\end{array}$ & 84,050 & 12,562 & 13,221 & 109,833 & 16.4 \\
\hline Clothing & 37,231 & 20,960 & 21,446 & 79,637 & 11.9 \\
\hline Health services & 29,821 & 6,095 & 3,632 & 39,548 & 5.9 \\
\hline social obligations & 26,802 & 6,400 & 16,514 & 49,716 & 7.4 \\
\hline Total & 392,233 & 154,881 & 123,376 & 670,490 & 100 \\
\hline Per capita expenditure & 985.5 & 469.34 & 380.8 & 637.4 & \\
\hline
\end{tabular}

\section{Income-expenditure Gap Analysis}

The income-expenditure gap analysis helps to compare the sources of income with their pattern of expenditure and measures household cash deficit (WFP, 2004). A household becomes vulnerable to food insecurity when the income obtained is not sufficient to purchase enough food or further investment. Accordingly, the balance between income and expenditure for the three agroecological zones was birr 25.9 per capita per year. Agro-ecologically, Dega was relatively better than Kolla and Woina-dega zones (Table 5). But from the three agro-ecological zones Woina-Dega was prone to cash deficit.

Table 5 Income-expenditure balances by agro-ecological zones (in birr)

\begin{tabular}{|l|l|l|l|l|}
\hline Agro-ecological zone & Income & Expenditure & Net balance & per capita per year \\
\hline Dega & 466,767 & 392,233 & 74,534 & 187.3 \\
\hline Woina-Dega & 99,948 & 154,881 & $-54,933$ & -166.5 \\
\hline Kolla & 131,083 & 123,376 & 7,707 & 23.8 \\
\hline
\end{tabular}

\section{Household Dietary Diversity Score (HDDS)}

Household dietary diversity is an important proxy indicator of food security because it is highly correlated with the factors such as calorie, protein and other food adequacy of the households. Dietary diversity is usually measured by summing the number of food groups consumed over a reference period (Kassie et al., 2008). Nine food groups were identified to measure HDDS. The food groups include: cereals, roots and tubers; Vitamin A rich plants like sweet potato; fruits; vegetables; meat/poultry/fish; eggs; legumes; milk and milk products and oil and/or butter (Kassie et al., 2008) (Table 6).

Table 6 Households' response to the groups of food consumed (\% of respondents)

\begin{tabular}{|l|l|l|l|l|}
\hline Food items consumed within 24 hours & $\begin{array}{l}\text { Dega } \\
(\mathrm{n}=70)\end{array}$ & $\begin{array}{l}\text { Woina-Dega } \\
(\mathrm{n}=70)\end{array}$ & $\begin{array}{l}\text { Kolla } \\
(\mathrm{n}=61)\end{array}$ & Total \\
\hline Grain, tubers, roots & 100 & 87.1 & 95.1 & 94.0 \\
\hline Legumes & 81.4 & 52.9 & 62.9 & 68.7 \\
\hline Cooked oils and fat & 41.4 & 18.6 & 9.8 & 23.9 \\
\hline Fruits & 7.1 & 1.4 & 5.7 & 5.0 \\
\hline Vegetables & 10 & 1.4 & 0.0 & 4.0 \\
\hline Eggs & 25.7 & 7.1 & 4.9 & 12.9 \\
\hline Milk and milk products & 45.7 & 2.9 & 3.3 & 17.9 \\
\hline Meat & 8.6 & 2.9 & 4.9 & 5.5 \\
\hline Vitamin A rich plants & 0.00 & 0.00 & 1.6 & 0.5 \\
\hline
\end{tabular}


As shown in Table 6 the dominant food groups consumed within 24 hours recall period were cereals and pulses which account for $94 \%$ and $68.7 \%$, respectively. The severe constraint of dietary diversity for the sampled households stemmed from their poverty, feeding habit and culture. In both agroecological zones the use of fruits, vegetables and eggs were low even though these types of food could be available in their surroundings. Key informants pointed that cabbage an important type dietary food is consumed only at the beginning of planting season but when productions are available, households do not prefer to eat and they consider a type of food consumed during food shortage. In relation to this, Tilaye (2006) pointed out that communities that depended more on cereals as source of food were more vulnerable to food insecurity than those with diversified food sources. Likewise, Babu and Sanyal (2009) asserted that lack of dietary diversity is a severe problem among poor populations in the developing world, because their diets are predominantly based on starchy staples/cereals and often include little or no animal products and vegetables.

According to Steyn (2006) cited in Kassie et al. (2008), dietary diversity score (DDS) below four is considered as nutritional inadequacy in the diet. The results showed that around $80 \%$ of the sampled households being subjected to dietary inadequacy because they were nourished less than three food groups (Figure 4). Agro-ecologically, around 50\% of the sampled households in Dega zone have consumed above four food items where as 95\% in Kolla and 93\% in Woina-Dega consumed less than four food items and they are prone to dietary deficiency.

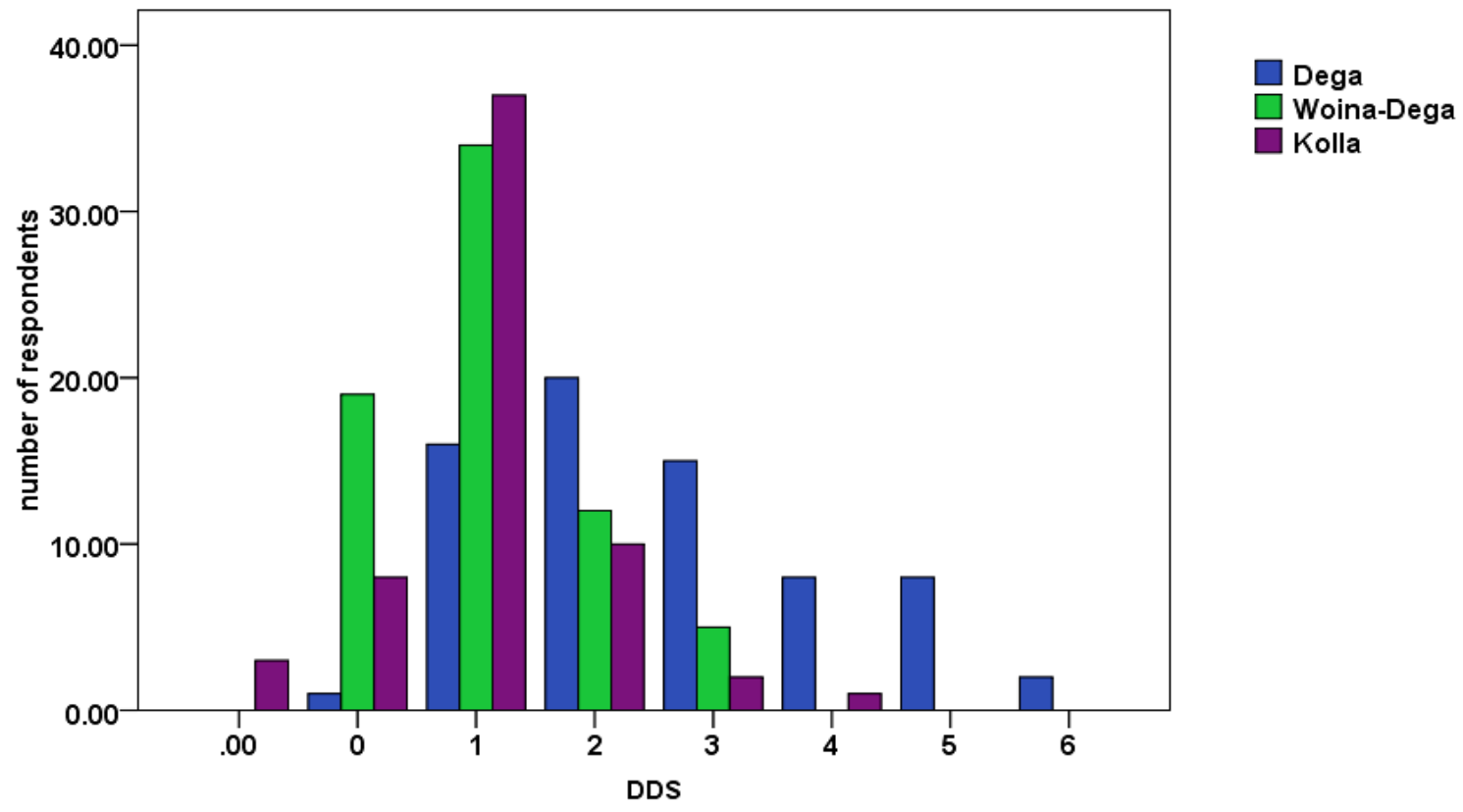

Figure 4 DDS by agro-ecological zone

In all agro-ecological zones, the mean DDS was calculated to be 2.60 and the standard deviation and the mode were 1.334 and 2, respectively (Figure 5). Smith et al. (2006) had calculated the DDS of Ethiopia and found that the mean was 4.7 and the percentage of households with low dietary diversity was $40 \%$ which was higher than the present study. 


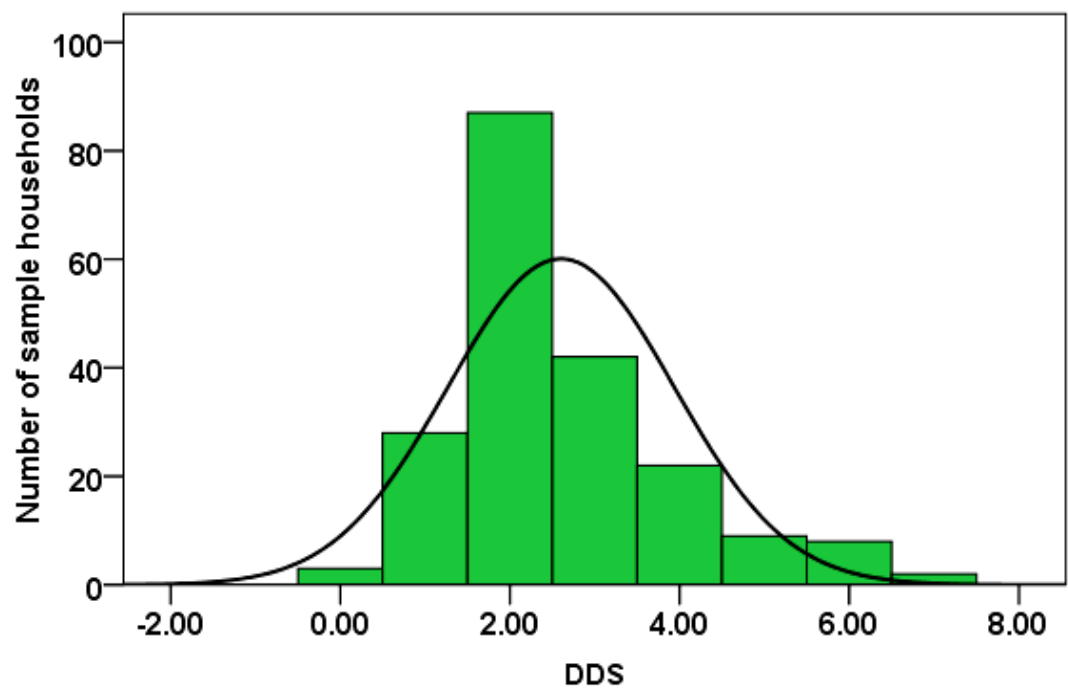

Mean $=2.60$

Std. Dev. $=1.334$

$\mathrm{N}=\mathbf{2 0 1}$

Figure 5 Frequency distribution of DDS of the sampled households

\section{Coping Strategy Index (CSI)}

People are not passive victim to unexpected shocks; they designed strategies based on the resources they owned to unusual, abnormal and adverse situations. In this regard, coping can be best illustrated as defense mechanisms, active way of solving problems and methods for handling resources for short term responses (Wisner et al., 2003). From the different coping strategies households employ during food shortage, 10 strategies commonly practiced by the sample households were selected (Table 7).

Table 7 Households' response to the questions of coping strategies and the weighted sum of the frequency of occurrences

\begin{tabular}{|c|c|c|c|c|c|c|c|c|c|}
\hline Strategy & 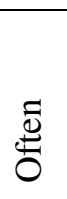 & 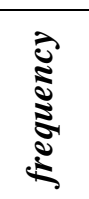 & $\begin{array}{l}\stackrel{9}{0} \\
\stackrel{\Xi}{\Xi} \\
\stackrel{\Xi}{\Xi}\end{array}$ & 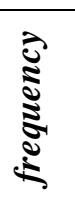 & 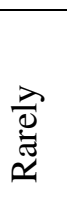 & 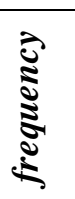 & 离 & 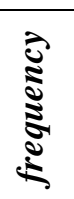 & $\begin{array}{l}\frac{\overrightarrow{0}}{0} \\
\frac{0}{00} \\
\frac{0}{0} \\
3\end{array}$ \\
\hline $\begin{array}{l}\text { Going without food throughout } \\
\text { the day }\end{array}$ & 33 & 132 & 141 & 423 & 21 & 42 & 6 & 6 & 603 \\
\hline Consuming wild foods & - & & - & - & 150 & 300 & 12 & 12 & 312 \\
\hline Selling land to purchase food & - & - & 21 & 63 & 30 & 60 & 120 & 120 & 243 \\
\hline $\begin{array}{l}\text { Reducing the number of } \\
\text { meals }\end{array}$ & 180 & 720 & 20 & 60 & 10 & 20 & - & - & 800 \\
\hline Consuming seed reserves & 32 & 128 & 90 & 270 & 86 & 172 & - & - & 570 \\
\hline $\begin{array}{l}\text { harvesting immature food } \\
\text { crops }\end{array}$ & 400 & 1600 & 20 & 60 & 14 & 28 & - & - & 1688 \\
\hline Selling livestock to buy food & 240 & 960 & 80 & 240 & 16 & 32 & - & - & 1232 \\
\hline $\begin{array}{l}\text { reducing the quantity of } \\
\text { meals }\end{array}$ & 101 & 404 & 30 & 90 & 7 & 14 & - & - & 508 \\
\hline $\begin{array}{l}\text { Consuming less preferred } \\
\text { food types }\end{array}$ & 120 & 480 & 5 & 15 & - & - & - & - & 495 \\
\hline Migrating to search job & 71 & 284 & 21 & 63 & 2 & 4 & - & - & 351 \\
\hline
\end{tabular}


The higher the weighted sum of the CSI, the higher could be the food insecurity status of the households. Accordingly, the highest weighted sum was harvesting immature crop (1688) followed by selling of livestock to purchase food (1232) and reduced number of meals (800). As the key informants ascertained, harvesting immature crops reduces the total crop production more than half, creating a vicious cycle of poverty which is an indicator of households' chronic food insecurity. Frequently sale of livestock erodes the productive capacity of the households. Reducing the number of meals, Going without food throughout the day and reducing the quantity of meals are all indicators of vulnerability to food insecurity.

\section{The Food Dietary Energy of the Sample Households}

The single most important indicator of food adequacy level of a community is the per capita dietary energy supply measured in kilocalorie (kcal). For the measurement of kcal per capita per day, it was vital to consider the quantity of every food item consumed by the households in the reference period (Table 8). Consequently, the total dietary food energy for the total sample households were 705,370,630 $\mathrm{kcal}$ and the total family into adult equivalent was 970 and the mean daily per capita kcal availability of the sample households was 1,990.9. Taking into account $2,100 \mathrm{kcal}$ the minimum requirement, the mean daily per capita kcal deficit for the entire sampled households was found to be 109.1.

Table 8 Households' income and expenditure balance sheet (in quintal)

\begin{tabular}{|l|l|l|l|l|l|l|l|l|}
\hline $\begin{array}{l}\text { Major } \\
\text { sources } \\
\text { of food }\end{array}$ & $\begin{array}{l}\text { Own } \\
\text { production }\end{array}$ & $\begin{array}{l}\text { Through } \\
\text { purchase }\end{array}$ & $\begin{array}{l}\text { Food } \\
\text { aid }\end{array}$ & $\begin{array}{l}\text { Through } \\
\text { transfer }\end{array}$ & $\begin{array}{l}\text { Seed } \\
\text { reserve } \\
(5 \%)\end{array}$ & $\begin{array}{l}\text { Post } \\
\text { harvest } \\
\text { lose }(10 \%)\end{array}$ & $\begin{array}{l}\text { Sales } \\
\text { from } \\
\text { crops }\end{array}$ & $\begin{array}{l}\text { Net } \\
\text { equiv } \\
\text {-alent }\end{array}$ \\
\hline Barely & 340.7 & 0.0 & 0.0 & 10.0 & 18.0 & 36.0 & 40.0 & 256.7 \\
\hline Wheat & 911.8 & 20.0 & 82.0 & 9.0 & 51.0 & 102.0 & 30.0 & 839.8 \\
\hline teff & 200.0 & 0.0 & 0.0 & 0.0 & 10.0 & 20.0 & 0.0 & 170.0 \\
\hline Pulses & 216.3 & 10.0 & 0.0 & 0.0 & 11.0 & 22.0 & 0.0 & 193.3 \\
\hline Potatoes & 656.2 & 132.0 & 0.0 & 0.0 & 39.0 & 78.0 & 0.0 & 671.2 \\
\hline Sorghum & 125.1 & 0.0 & 0.0 & 0.0 & 6.3 & 12.5 & 0.0 & 106.3 \\
\hline Maize & 226.0 & 201.0 & 0.0 & 32.0 & 12.0 & 46.0 & 0.0 & 401.0 \\
\hline Millet & 4.0 & 0.0 & 0.0 & 0.0 & 0.2 & 0.4 & 0.0 & 3.4 \\
\hline Total & 2680.1 & 363.0 & 82.0 & 51.0 & 147.5 & 316.9 & 70.0 & 2641. \\
\hline
\end{tabular}

According to Devereux (2006) consistently above $2,100 \mathrm{kcal}$ are food secure; between 1800 and $2100 \mathrm{kcal}$ mildly food insecure; between 1500 and $1800 \mathrm{kcal}$ moderately food insecure and less than $1500 \mathrm{kcal}$ per day are severely food insecure. According to this criteria, $65.7 \%$ were severely food insecure, $11.9 \%$ moderately food insecure, $2 \%$ mildly food insecure and $20.4 \%$ were food secure.
Based on the minimum requirements of kcal per capita per day, $48 \%$ of the sampled households' in Dega, 82\% in Kolla and 92.9\% in Woina-Dega zones were food insecure. The mean per capita kilocalories per day was higher in Dega than the other zones (Table 9). In general, around $80 \%$ of the total sampled households were food insecure

Table 9 The mean per capita kcal per day by agro-ecological zone

\begin{tabular}{|l|l|l|l|l|}
\hline Agro-ecological zone & Minimum & Maximum & Mean & Range \\
\hline Dega & 120 & 8257 & 2172 & 8137 \\
\hline Woina dega & 83 & 7417 & 1613 & 4715 \\
\hline Kolla & 109 & 4824 & 1825 & 7334 \\
\hline
\end{tabular}


Studies related to dietary energy affirm that kilocalorie deficiency is one of the main causes of food insecurity in Ethiopia. Smith et al. (2006) ascertained the prevalence of food energy supply deficiency among the study countries in Africa ranging from $37 \%$ for Uganda and $73.3 \%$ for rural Ethiopia with the average kcal intake of 1,827. Devereux (2006) the study made in rural Wollo argued that $44.3 \%$ of the sampled households were chronic food insecure with per capita kilocalorie availability of less than 1500 . These empirical evidences suggested that the per capita per day kcal deficiencies identified in the study area were not uncommon to other parts of Ethiopia.

In-depth interviews were conducted to substantiate the major findings of the quantitative parts. Unpredictable rainfall, land degradation, poor infrastructure and poor asset ownership were the challenges for the majority of the households. Finally, based on households dietary diversity, dietary energy supply, coping strategy index, food gap analysis, variability of rainfall, the severity of land degradation and the conditions of infrastructure, the food security map of Lay Gaint district in South Gondar administrative zone where produced (Figure 6). Consequently, large areas of Woina-Dega and Kolla zones located in the eastern and northern parts of the district were chronically food insecure. During the field survey, the district food security expert, the key informants and focus group discussion participants have also confirmed that Woina-Dega and Kolla zones are highly food insecure and the majority of the households (above 60\%) are members of the government's productive safety net program.

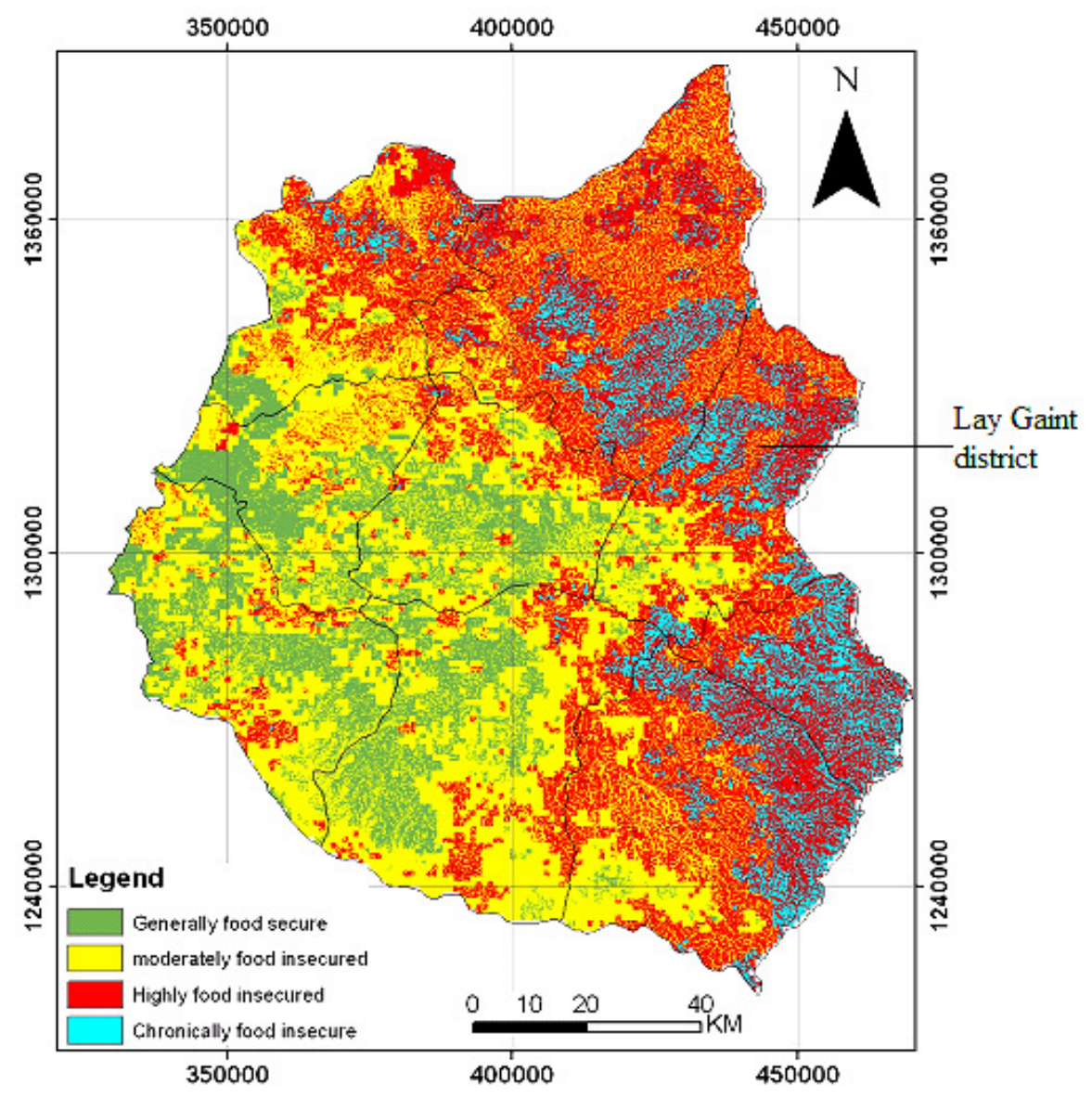

Figure 6 Food Security Map of Lay Gaint in South Gondar Administrative Zone Source: Birhanu (2009) 


\section{Determinants of household's per capita kilocalorie supply}

The model selected was linear regression because the dependent variable, per capita kilocalorie intake is a continuous variable. Dietary energy supply measured in kilocalorie is an imperative measure of food security in an area where the majority of the households face challenges to meet at least one components of food security, i.e., food availability. Different parameters were employed to check the fitness of the model. The F-ratio was highly significant at $\mathrm{P}<0.001$. This showed that at least one or more of the independent variables likely to have significant relationship to the dependent variable. The multicollinearity of the independent variables ranges in between 0.0 and 0.7 and was not a problem to the model fit. Eleven variables were entered into the model and seven variables were statistically significant (Table 10).

Table 10 Multiple Regression results
It was assumed that total yield has significant and positive correlation to the per capita kilocalorie intake of the sampled households. Other variables being constant, an increase of total production by 1 unit produced increase the per capita kilocalorie intake by a factor of 0.844 at $\mathrm{p}<0.001$. The result is also consistent with the previous studies of Babatunde et al. (2010). It was hypothesized that large family size has significant and negative correlation to the total per capita kcal availability of the family. But the regression result showed the reverse of the stated assumption. Other variables being constant an increase of family size by one unit the per capita kcal supply increases by a factor of 0.178 at $\mathrm{p}<0.001$. Frakenberger et al. (2007) have also reached similar result.

\begin{tabular}{|c|c|c|c|c|}
\hline Variable & Unstandardized Coff. & Standardized coff. & $\mathrm{t}$ & Sig \\
\hline & $B$ & $B$ & & (P value) \\
\hline (Constant) & 2.123 & & 2.364 & 0.019 ** \\
\hline nonfarm & 0.324 & 0.057 & 1.325 & $0.187^{\mathrm{NS}}$ \\
\hline household size & -133.923 & -0.178 & -2.717 & $0.007 * * *$ \\
\hline age & 0.008 & 0.045 & 1.061 & $0.290^{\mathrm{NS}}$ \\
\hline sex & -0.571 & -0.081 & -1.882 & $0.061 *$ \\
\hline total yield & 0.115 & 0.844 & 12.684 & $0.000 * * *$ \\
\hline agro-ecological zone & 0.291 & 0.096 & 2.036 & $0.043 * *$ \\
\hline oxen & 366.232 & 0.252 & 2.881 & $0.004 * * *$ \\
\hline total livestock & 41.614 & 0.271 & 3.179 & $0.002 * * *$ \\
\hline number of plots & 239.758 & 0.220 & 3.426 & $0.001 * * *$ \\
\hline credit & -0.110 & -0.022 & -0.540 & $0.590^{\mathrm{NS}}$ \\
\hline total income & -0.020 & -0.057 & -0.905 & $0.367^{\mathrm{NS}}$ \\
\hline
\end{tabular}

The regression result showed that livestock and number of oxen owned were positively and significantly correlated to per capita kcal supply at $\mathrm{P}<0.01$. Other variables being constant an increase of one unit of ox and livestock increases the per capita kcal supply of the household by a factor of 0.252 and 0.271 , respectively. The result is supported by Deressa et al. (2008).
It was predicted that sex of the household head has negative and significant correlation to per capita kcal availability. Other variables being constant a unit increase of female headed household decreases the per capita kcal consumption by a factor of 0.081 at $\mathrm{p}<0.1$. This result was consistent to the previous studies by Babatunde et al. (2010). In general, stepwise regression analysis showed that the total independent variables had explained 
$71.1 \%$ of the total variances of the dependent variable. The five most important determinant variables total yield, household size, agroecological zone, number of oxen and total income had explained $70.2 \%$ of the variances in the dependent variable.

\section{Conclusions}

Identifying food secure and insecure households and regions using indicators have paramount importance to take interventions. Kassie et al. (2008) focused on DDS, while Eshetu (2000) has investigated the dietary food energy supply and Deressa et al. (2010) employed the coping strategy index in different parts of Ethiopia. These showed that studies related to food security indicators in Ethiopia by no means are not holistic. Perceiving this gap, the current study had made holistic and used both quantitative and qualitative food security indicators to determine the food secure and insecure households. The study revealed that HDDS is dominated by cereals and legumes which account for $94 \%$ and $68.7 \%$, respectively. Based on the results of the per capita kcal intake, $58.7 \%, 7.5 \%, 8 \%$ and $20.4 \%$ were severely food insecure, moderately food insecure, mildly food insecure and food secure, respectively. The per capita kilocalorie result confirmed that around $80 \%$ of the sampled households were food insecure. Agro-ecologically, Kolla (87\%) and WoinaDega $(93 \%)$ of the sample households were food insecure. The linear regression results confirmed that total yield per capita, household size, agro-ecological zone, number of oxen and total income were determinant variables in per capita kilocalorie availability of the sample households. Therefore, it is recommended among others, enhancing the kilocalorie supply of the poor households through crop and livelihood diversification has to be given top priority by decision makers. Besides, selective interventions have to be given to the poorest, female headed households and the disadvantageous agroecological zones to ensure household food security.

\section{References}

Alwang, J., Seigel, P. and Jǿrgensen, S. (2001). Vulnerability: A View from Different Disciplines, Social Protection. Discussion Paper Series, No. 0115. Human Development Network, the World Bank.

Babatunde, R., Adejobi,A. and Fakayode, O. (2010). Income and Calorie Intake among Farming Households in Rural Nigeria: Results of Parametric and Nonparametric Analysis. Journal of Agricultural Science 2(2):135-146, Nigeria.

Babu, S. and Sanyal, P. (2009). Food Security, Poverty and Nutrition Policy Analysis: Statistical Methods and Applications. Elsevier, USA.

Bezabih, E. (1999). Attaining Household Food Security through Adoption of New Agricultural Technologies: The Case of Smallholders in Eastern Ethiopia. University of Hannover, Institute for Horticultural Economics.

Bickel, G., Nord, M., Price, C., Hamilton, W. and Cook J. (2000). Measuring Food Security in the United States: Guide to Measuring Household Food Security, USDA.

Birhanu, G. (2009). Delineation of Food Insecure Areas using Remote Sensing and GIS (Food Availability Analysis): The Case of South Gondar Zone. Unpublished MSC Thesis, Addis Ababa University, Ethiopia.

CSA. (2010). The 2007 Population and Housing Census of Ethiopia, National Statistical Summary Report, EDRE, Ethiopia.

Debebe, H. (1995). Food Security: A Brief Review of Concepts and Indicators. In Mulat (eds.) Proceedings of the Inaugural and Annual Conference of the Agricultural Economics Society of Ethiopia, Addis Ababa, Ethiopia.

Deressa, T., Ringler, C. and Hassan, R. (2010). Factors Affecting the Choices of Coping Strategies for Climate Extremes: The Case of Farmers in the Nile Basin of Ethiopia. Department of Agricultural Economics and Rural Development, University of Pretoria.

Devereux, S. (2006). Distinguishing between Chronic and Transitory Food Insecurity in Emergency Needs Assessments. World Food Programs, Emergency Needs Assessment Branch (ODAN), Rome, Italy. 
Ellis, F. and Bahiigwa, G. (2003). Livelihoods and Rural Poverty Reduction in Uganda. World Development 31(6): 997-1013. Elsevier Science Ltd. Printed in Great Britain. Ellis, F. and Tassew, W. 2005. Ethiopia Participatory Poverty Assessment 2004-05. Ministry of Finance and Economic Development, Development Planning and Research Department. Published by MOFED, Addis Ababa, Ethiopia.

Eshetu, B. (2000). The Underlying Causes of Households' Food Insecurity and Coping Strategies. The Case of Ligamboo Woreda, South Wollo Zone, Amhara Region, Northern Ethiopia. Unpublished MA Thesis, Addis Ababa University.

Frankenberger, T., Sutter, P. and Teshome, A. (2007). Ethiopia: The Path to Self Resilience. Final Report, Prepared for Canadian Network of NGOs in Ethiopia.

Frankenberger, T. (1992). Indicators and Data Collection Methods for Assessing Household Food Security: Household Food Security, Concepts, Indicators and Measurement.

Hoddinott, J. (1999). Choosing Outcome Indicators of Household Food Security. International Food Policy Research Institute, Washington D.C.

Kassie, G. T., Asfaw, W., Zeleke, G. and Scott, D. (2008). The Nexus of Migration, HIV/AIDS and Food Security in Ethiopia. Global Mountain Program of the CGIAR, Addis Ababa, Ethiopia, IFPRI/Renewal, South Africa.

Maxwell, D. (2008). The Coping Strategy Index: A Tool for Rapid Measurement of Household Foods and the Impact of Food Aid Programs in Humanitarian Agencies. Field
Method Manual, Second Edition, TANGO, USAID, WFP and CARE.

Bogale, A. and Shimelis, A. (2009). Household Level Determinants of Food Insecurity in Rural Areas of Dire Dawa, Eastern Ethiopia. Journal of Ajfand 9(9):1914:1926.

Qureshi, S. (2007). Creating an Index to Measure Food Security: Identifying the Components and Determinants and Testing Usefulness. Heller School for Social Policy and Management Brandies University.

Samuel, G. (2004). Food Insecurity and Poverty in Ethiopia: Evidence and Lessons from Wollo. EEA/EECPRI, Working Paper, No.3, Addis Ababa, Ethiopia.

Smith, C., Alderman, H. and Aduayom, D. (2006). Food Insecurity in Sub-Saharan Africa New Estimates from Household Expenditure Surveys. International Food Policy Research Institute, Washington, D C.

Tilaye, T. (2006). Food Insecurity: Extent, Determinants and Household Coping Mechanisms in Gera Keya Woreda, Amhara Region. Ermias, A., Akalu, T and Alemayehu, A. (eds.) Proceedings of the 1st Annual Regional Conference on Completed Crop Research Activities. Amhara Regional Agricultural Research Institute, Bahir Dar.

WFP. (2004). Emergency Food Security Assessment Handbook.

Wisner, B., Blaikie, P., Cannon, T and Davis, I. (2003). At Risk: Natural Hazards, People's Vulnerability and Disasters. Second Edition, Rutledge Inc. 